\title{
Preliminary Evaluation of Hepatorenal Protective Potentials of Kigelia africana Ethanolic Leaf Extract on Carbon Tetrachloride Induced Toxicity in Adult Male Wistar Rats
}

\author{
Wandiahyel Yaduma Gaiuson ${ }^{1}$ (D), Nachamada Emmanuel Solomon²*, Neftiya Yaduma33, \\ Ibrahim Malgwi Samaila4, Dluya Thagriki ${ }^{5}$

\footnotetext{
${ }^{1}$ Department of Chemistry, School of Life Science, Adamawa State College of Education, Hong Yola, Nigeria

${ }^{2}$ Department of Human Physiology, Faculty of Basic Medical Sciences, College of Medical Sciences, Ahmadu Bello University, Zaria, Kaduna State, Nigeria

${ }^{3}$ Department of Zoology, Faculty of Sciences, Adamawa State University, Mubi, Nigeria

${ }^{4}$ Department of Human Physiology, College of Medical Sciences, University of Maiduguri, Borno, Nigeria

${ }^{5}$ Department of Biochemistry, Faculty of Sciences, Adamawa State University, Mubi, Nigeria

Email: *nesolomon@yahoo.com
}

How to cite this paper: Gaiuson, W.Y., Solomon, N.E., Yaduma, N., Samaila, I.M. and Thagriki, D. (2020) Preliminary Evaluation of Hepatorenal Protective Potentials of Kigelia africana Ethanolic Leaf Extract on Carbon Tetrachloride Induced Toxicity in Adult Male Wistar Rats. American Journal of Plant Sciences, 11, 1345-1359.

https://doi.org/10.4236/ajps.2020.119096

Received: August 2, 2020

Accepted: September 12, 2020

Published: September 15, 2020

Copyright $\odot 2020$ by author(s) and Scientific Research Publishing Inc. This work is licensed under the Creative Commons Attribution International License (CC BY 4.0).

http://creativecommons.org/licenses/by/4.0/

\section{(c) (i) Open Access}

\begin{abstract}
Background and aim: Hepatorenal toxicity is a very common ailment with resultant deleterious burden on the overall body systems and high mortality rate. Although myriads of drug agents are in circulation, its medical management is still inadequate as no effective treatment which inhibits disease progression and complications, has been synthesized yet. Therefore, this study focused on the potentials of Kigelia africana ethanolic leaf extract (KAELE) in preventing hepatorenal toxicity using $\mathrm{CCl}_{4}$ model of toxicity in rats. Method: KAELE was subjected to phytochemical screening. Following two-week acclimatization, thirty-six $(\mathrm{N}=36)$ adult male Wistar rats were grouped into six consisting of six animals each $(n=6)$. Group I was given distilled water as control while groups II to VI received silymarin (100 $\mathrm{mg} / \mathrm{kg}), \mathrm{CCl}_{4}(1 \mathrm{ml} / \mathrm{kg}), \mathrm{KAELE}(100 \mathrm{mg} / \mathrm{kg}, 200 \mathrm{mg} / \mathrm{kg}$ and $400 \mathrm{mg} / \mathrm{kg}) \mathrm{re}-$ spectively. All groups pre-treated with silymarin and Kigelia africana ethanol leaf extract lasted for a period of fourteen (14) days using a gastric tube. $\mathrm{CCl}_{4}$ was administered intraperitoneally to groups II, III, IV, V and VI 48 hours after the last pretreatment on day 14. Post treatment, animals were sacrificed and the blood obtained and sera used for biochemical analysis while the tissues for histological evaluations. Results. The phytochemical tests revealed the presence of flavonoids, tannins, steroids, terpenoids, saponins, glycosides,
\end{abstract}


alkaloids, and phenols. There was a significant decrease $(\mathrm{P}<0.05)$ in the level of all serum liver enzymes (AST, ALT and ALP) in the extract-treated groups. KAELE showed a dose-dependent hepato-protective property as it significantly mitigated the effects of carbon tetrachloride on the liver function markers studied (total bilirubin, conjugated bilirubin, albumin and total protein). KAELE showed the decrease necrotic hepatic plates around the portal areas and damaged blood vessels with less fatty acids infiltrations in this study. Conclusion: KAELE possesses hepatorenal protective potentials.

\section{Keywords}

Kigelia africana, Phytochemicals, Hepatotoxicity, Renal Toxicity, $\mathrm{CCl}_{4}$

\section{Introduction}

Some medicinal plants play major roles in the management of various liver disorders along with other system related diseases. Liver which is the key organ regulating homeostasis within the body by various functions is susceptible to injuries triggered by toxic chemicals and drugs among others [1] [2]. Although newly developed drugs have been used to treat and manage chronic liver disorders; these drugs often present with plethora of side effects [3]. Additionally, metabolism disorders including serum electrolytes, urea and creatinine derangement are possible in the presence of carbon tetrachloride over dosage [4]. Increased concentration of serum urea and creatinine is considered for investing drug induced nephrotoxicity in mammals [5]. Several studies suggest that traditional herbs and micronutrients such as carotenoids and selenium may be useful. Their therapeutic abilities are consequence of bioactive constituents present with the propensity to elicit definite physiological activities when exposed to the human body [6]. These bioactive constituents range from alkaloids, tannins, flavonoids, saponins, lignins, lignans, cyanogenic glycoside and phenolic compounds among others. Plant derived natural products such as flavonoids, terpenoids and steroids have received considerable attention in recent years due to their diverse pharmacological properties including antioxidant and hepatoprotective activity [7]. Kigelia africana is a genus of flowing plants in the family bignoniaceous. The genus comprises only one species, $K$. Africana. It is widely spread in Sub-Saharan Africa, although rare in some regions. The plant contains naphthoquinones which are active against several protozoal species [8] [9] [10]. The bark of $K$. africana Lam. (Benth) as powder is used in traditional medicine for ulcers treatment, or for treatment of pneumonia and malaria. The ethanolic stem bark extract of plant can stimulate a central nervous system in which by this property the plant can be explored for therapeutic advantage [11], alongside its antibacterial activity, antioxidant activity and antidiabetic activity [12] [13]. The major constituents isolated from the polar extract of the fruit of $K$. africana are verminosides and iridoids and series of polyphenols such as ver- 
bascoside. Also in vitro assays showed that verminoside had significant anti-inflammatory effects [14]. The plant has many medicinal properties because of the presence of many secondary metabolites which include iridoids, flavonoids, and napthoquinones and volatile constituents [15]. Hence the present study investigated the phytochemicals and hepatorenal protective potential of ethanolic leaf extract of $K$. africana in adult male Wistar rats.

\subsection{Materials and Methods}

\subsubsection{Plant Materials}

The plant leaves were collected from the study area; Girei Local Government, Adamawa State Nigeria. The study area lies on latitude $9^{\circ} 21^{\prime} 53.19^{\prime \prime}$ North and longitude $12^{\circ} 33^{\prime} 28.33^{\prime \prime}$ East, Google earth (2014). The fresh plant (leaf) was identified and authenticated in the Department of Plant Science, Modibbo Adama University of Technology Yola Adamawa State.

\subsubsection{Preparation of Ethanol Extract}

The fresh leaf of Kigelia africana was washed with tap water and then rinsed with distilled water. The leaf of Kigelia africana was air dried under room temperature for 14 days, cut into small pieces and pulverized using pestle and mortar. Powdered leaf was used for the preparation of ethanol extract. Ethanolic extract was prepared by suspending $200 \mathrm{~g}$ of the powdered sample in $2 \mathrm{~L}$ of ethanol for 24 hours at room temperature, after which it was filtered using a filter paper and then concentrated at $55^{\circ} \mathrm{C}$ using a water bath [16].

\subsection{Ethical Approval}

Animals were handled and used in concert with the guidelines of the National Institute of Health guide for the care and use of laboratory animals (Washington (DC): National Academies Press (US) [17].

\subsection{Experimental Animals}

Thirty-six (36) adult male Wistar rats between 120 - $180 \mathrm{~g}$ body weights were obtained from the animal house of the National Veterinary Research Institute (NVRI) Vom, Plateau State Nigeria. The animals were controlled and monitored in plastic cages containing sawdust as bedding material with routine cleaning and disinfection throughout the period of study. The animals were maintained on standard laboratory diet and water ad libitum (Figure 1).

\subsection{Experimental Design}

Following two (2) weeks of acclimatization, thirty-six $(\mathrm{N}=36)$ adult male Wistar rats were grouped into six groups of six animals each $(n=6)$ as shown in Figure 2. All groups pre-treated with silymarin and Kigelia africana ethanol leaf extract lasted for a period of fourteen (14) days using a gastric tube. $\mathrm{CCl}_{4}$ was administered intraperitoneally to groups II, III, IV, V and VI 48 hours after the last pretreatment on day 14 . 


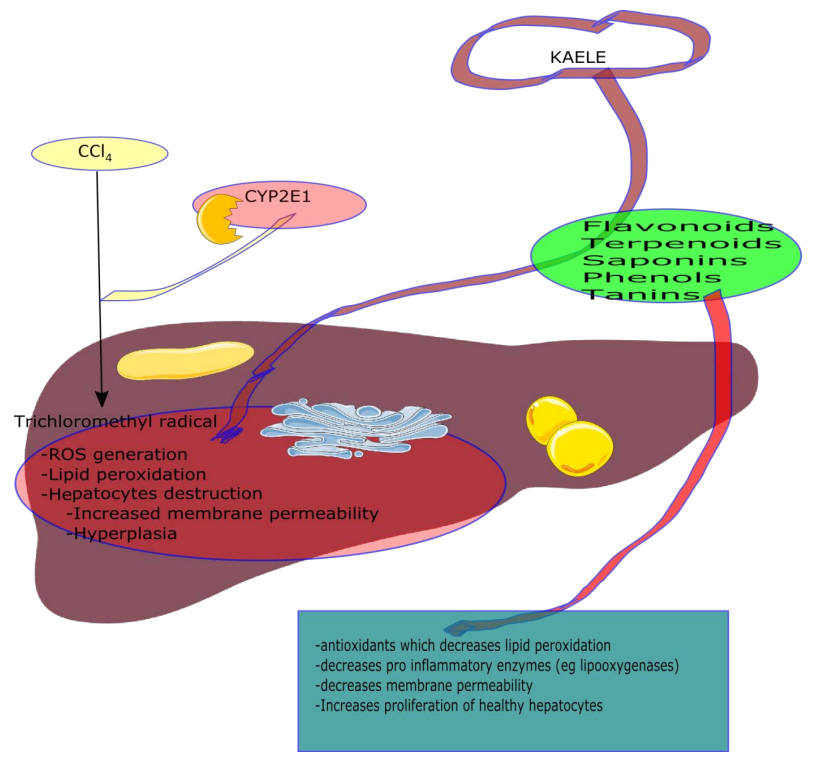

Figure 1. Possible mechanisms of action for KAELE in adult Wistar rats. Polyphenols in KAELE decreases lipid peroxidation by mopping off ROS and increased proliferation of healthy hepatocytes.

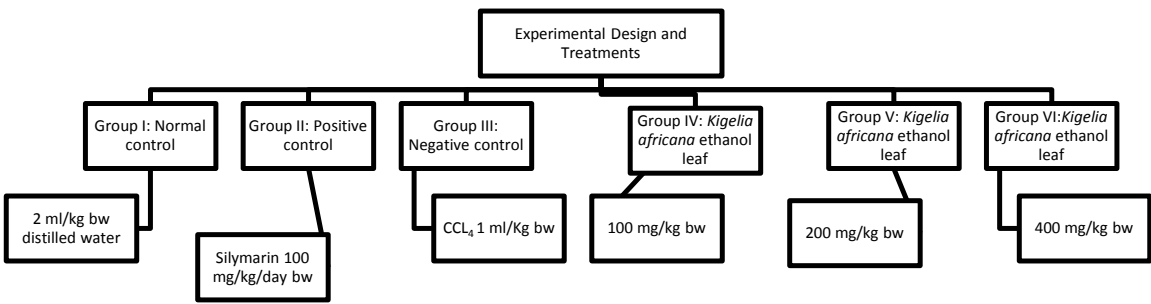

Figure 2. Animal groupings and experimental design.

\subsection{Preliminary Phytochemical Screening of Kigelia africana Ethanol Leaf Extract}

\subsubsection{Qualitative Phytochemical Analysis}

The leaf extract was screened for alkaloids, flavonoids, steroids, phenols, and tannins, glycosides, and proteins. The tests for carbohydrate, glycosides, phenols and tannins were carried out according to the method of Harbone [18]. Tests for saponin, terpenoids and flavonoids were carried out according to the method described by Senthilkumar and Reetha [19]. Alkaloids, proteins and steroids were tested according to the method described by Nweze [20].

\subsubsection{Quantitative Phytochemical Analysis}

Tannin and terpenoid were estimated as tannic acid according to the method of Ferguson [21]. Terpenoid was also estimated by the method of Ferguson [21]. Estimation of alkaloid was carried out according to the method described by Harbone [17]. Flavonoid was estimated according to the method of Bolun and Kocipai-Abyazan [22], while saponin estimation was carried out as described by Obdoni and Ochuko [23]. Total phenol was estimated using a spectrophotometric method as described by Edeoga [24]. 


\subsection{Animal Sacrifice}

Animals were anaesthetized in a chloroform chamber following 24 hours fasting and blood samples obtained via cardiac puncture using $5 \mathrm{ml}$ syringes into plain tubes from which sera were collected by centrifugation at $5000 \mathrm{rpm}$ for $5 \mathrm{mi}$ nutes. The sera were used for biochemical assessments.

\subsection{Liver Biochemical Assessments}

The colorimetric end-point method of Reitman and Frankel [25] was used for assaying for AST and ALT levels in the samples, using Randox test kits. The p-nitro-phenol method described in Bormers and McComb [26] was used to evaluate ALP activity using Randox test kit.

\subsection{Renal Biochemical Assessments}

Jendrassik and Grof method described by Doumas [27] was used for assaying direct bilirubin levels in the samples, using Randox test kit. The Biuret method described in Reinhold [28] was used to evaluate total protein level using Randox test kit. Albumin was assayed according to the method described by Reinhold [28]. Ammonia was measured photometrically by Berthelot's reaction while creatinine was determined by the method of Jaffe [29].

\subsection{Histopathological Examination}

Livers were excised from experimental animals and weighed, then preserved in $10 \%$ formalin solution for histological assessment. The specimens were afterwards trimmed, washed and dehydrated in ascending grades of alcohol then rinsed with xylol and embedded in paraffin. Sections of $4-6$ microns were made and stained with hematoxylin and eosin and the slides examined [30].

\subsection{Statistical Analyses}

All values were express as Mean \pm SEM (Standard Error of Mean). One-way analysis of variance (ANOVA) was employed followed by Tukey post hoc test.

\section{Results}

\subsection{Phytochemical Compositions of KAELE}

Table 1 shows the phytochemical composition of KAELE with flavonoids having the highest percentage of 24.08 , followed by terpenoids, tanins and saponins.

\subsection{The Effect of Pre-Treatment with Kigelia africana Ethanol Leaf Extracts on Serum AST, ALT and ALP Levels in Adult Male Wistar Rats}

The serum level of AST, ALT, and ALP in Figures 3-5 significantly increased in $\mathrm{CCl}_{4}$ only treated group compared to normal $(P<0.05)$. There was a statistically significant dose dependent decrease in the liver enzymes $(P<0.05)$ of all the 
extract treated groups compared to the $\mathrm{CCl}_{4}$ only treated group. However, these serum liver enzymes were significantly increased in both $\mathrm{CCl}_{4}$ only treated group and the extract at $100 \mathrm{mg} / \mathrm{kg}$ compared to the silymarin $(100 \mathrm{mg} / \mathrm{kg})$ treated group. Significant changes $(P<0.05)$ were observed with high dosage of extract in Figures 3-5.

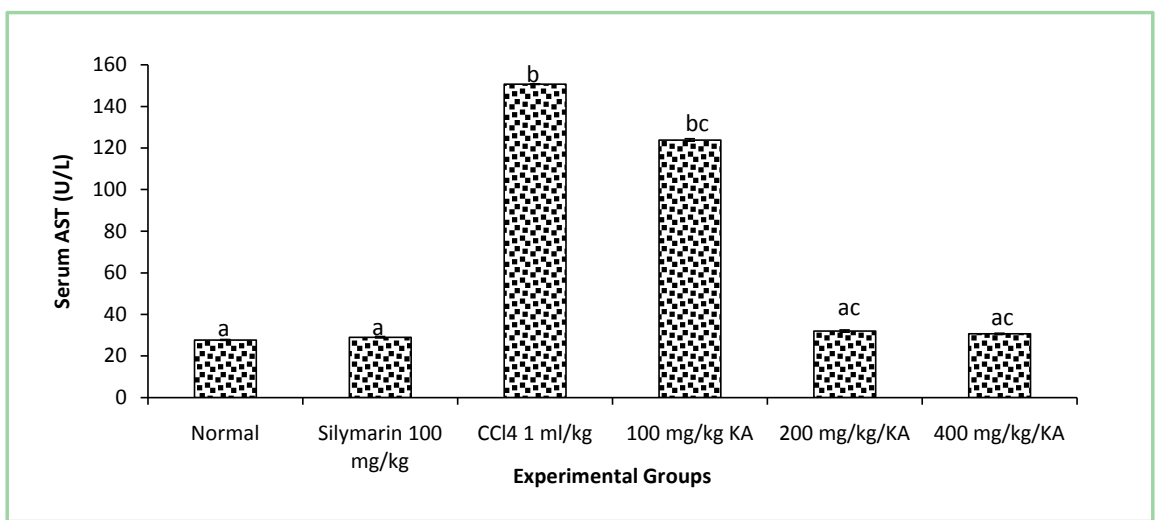

Figure 3. Different superscripts $(\mathrm{a}, \mathrm{b})$ indicate statistical significant difference $(P<0.05)$, (c) indicate significant difference $(P<0.05)$, compared to $\mathrm{CCL}_{4}$ treated group.

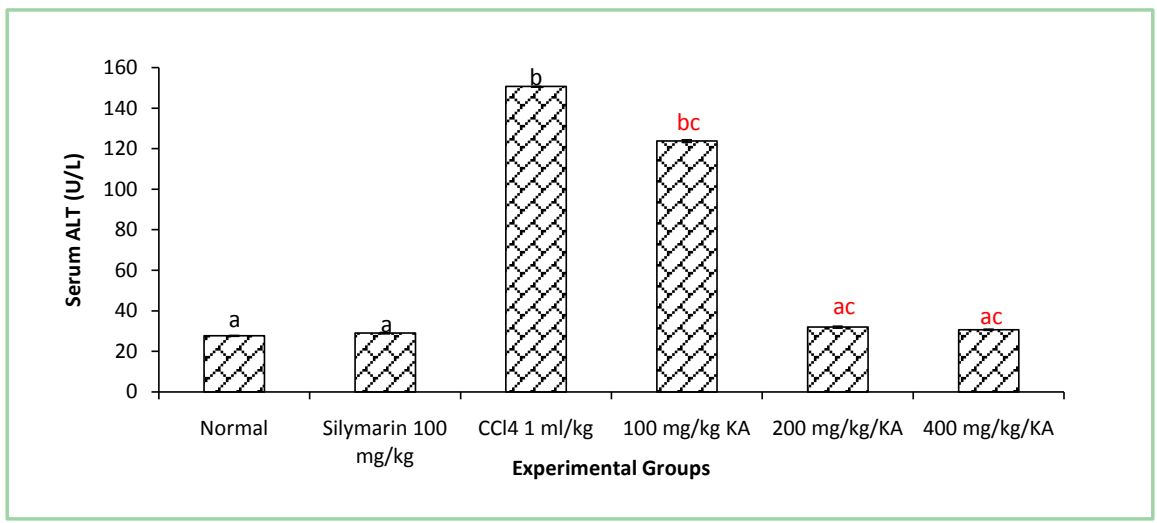

Figure 4. Different superscripts $(\mathrm{a}, \mathrm{b})$ indicate statistical significant difference $(P<0.05)$, (c) indicate significant difference $(P<0.05)$, compared to $\mathrm{CCL}_{4}$ treated group.

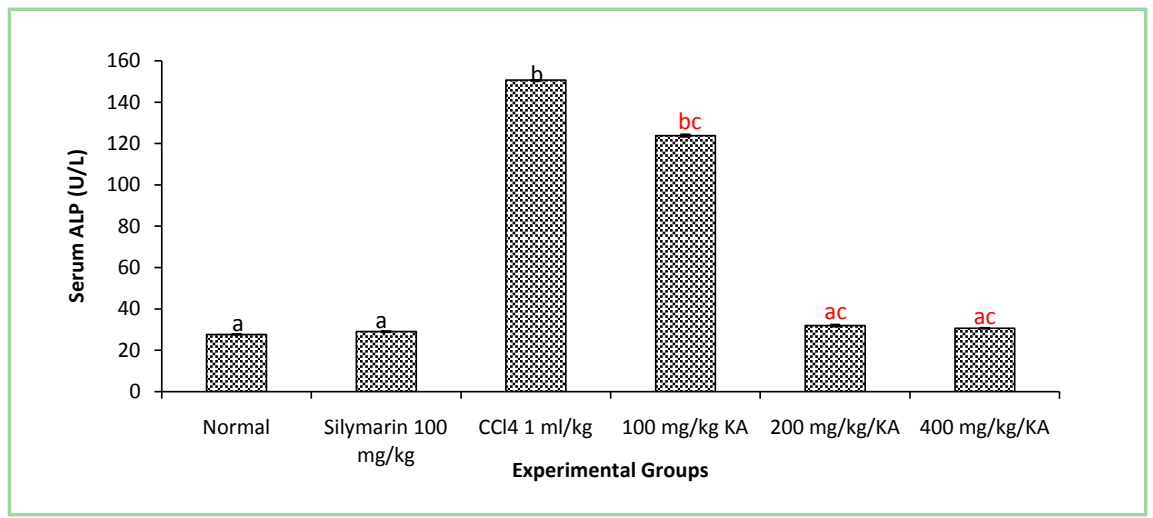

Figure 5. Different superscripts $(\mathrm{a}, \mathrm{b})$ indicate statistical significant difference $(P<0.05)$, (c) indicate significant difference $(P<0.05)$, compared to $\mathrm{CCL}_{4}$ treated group. 
Table 1. Phytochemical compositions of Kigelia africana ethanol leaf extract.

\begin{tabular}{ccc}
\hline Phytochemicals & Qualitative Composition & Percentage (\%) \\
\hline Alkaloids & + & $1.27 \pm 0.01$ \\
Flavonoids & + & $24.08 \pm 0.42$ \\
Phenols & + & $5.05 \pm 0.06$ \\
Terpenoids & + & $18.43 \pm 0.52$ \\
Saponins & + & $12.41 \pm 0.50$ \\
Steriods & + & $2.27 \pm 0.60$ \\
Tannins & + & $16.20 \pm 0.18$ \\
\hline
\end{tabular}

Key: Present: + .

\subsection{The Effect of Pre-Treatment with Kigelia africana Ethanol Leaf Extracts on Serum Conjugated Bilirubin, Total Bilirubin, Total Albumin and Total Protein Levels in Adult Male Wistar Rats}

In Table 2 serum $\mathrm{CB}, \mathrm{TB}$, albumin and $\mathrm{TP}$ were all increased significantly $(\mathrm{P}<$ $0.05)$ in the $\mathrm{CCl}_{4}$ control groups compared to both the normal control and silymarin treated group. $\mathrm{CB}, \mathrm{TB}$, albumin and $\mathrm{TP}$ were also significantly higher $(\mathrm{P}<$ $0.05)$ in $100 \mathrm{mg} / \mathrm{kg}$ extract treated group compared to both normal control and silymarin treated group. $\mathrm{CB}, \mathrm{TB}$, albumin and TP levels in the extract treated groups; 200 and $400(\mathrm{mg} / \mathrm{kg})$ were significantly lower compared to the 100 $\mathrm{mg} / \mathrm{kg}$ extract treated group.

\subsection{Effect of Pre-Treatment with Kigelia africana Ethanol Leaf Extract on Some Kidney Function Parameters}

The level of $\mathrm{Na}^{+}(\mathrm{mmol} / \mathrm{L}), \mathrm{K}^{+}(\mathrm{mmol} / \mathrm{L}), \mathrm{Cl}^{-}(\mathrm{mmol} / \mathrm{L}), \mathrm{HCO}_{3}^{-} \quad(\mathrm{mmol} / \mathrm{L}), \mathrm{Ur}$ $(\mathrm{mmol} / \mathrm{L})$, and $\mathrm{Cr}(\mathrm{mmol} / \mathrm{L})$ in Table 3 showed a significant increase in $\mathrm{CCl}_{4}$ control and $100 \mathrm{mg} / \mathrm{kg}$ extract treated group compared to normal control. Although the levels of theses electrolytes were decreased in all the extract treated groups, however, the decrease was only statistically significant in $400 \mathrm{mg} / \mathrm{kg}$ treated group compared to $\mathrm{CCl}_{4}$ only treated group.

\subsection{Effect of Pre-Treatment with Kigelia africana Ethanol Leaf Extract on Liver Histology}

Figure 6 shows a well preserved liver architecture consisting of normal hepatocytes $(\mathrm{NH})$ with well-preserved cytoplasm, prominent nucleus and well brought out central vein. Figure 7 shows coarse surrounding hepatocytes with active blood circulation and well organized portal areas. In Figure 8, there is abnormality in the liver architecture characterized by necrosis of hepatic lobules and plates $(\mathrm{HN})$ around the portal areas with destruction of blood vessels. Damaged nuclei appear with ovoid nuclei, prominent nucleoli and acidophilic 
cytoplasm. Additionally, there is also moderate presence of fatty acids (MF) and changes consistent with inflammatory cells. Figure 9 shows hepatic lobules displaying necrosis of hepatic plates denoted by FC around the portal area with marked destruction of blood vessels. There is also marked presence of fatty changes and some inflammatory cells. Figure 10 shows normal hepatic lobules $(\mathrm{NH})$ displaying hepatic plates with moderate sinusoidal spaces. Its hepatocytes are ovoid and vesicular with some prominent nucleoli and slight coarse granular acidophilic cytoplasm. It also shows central vein containing blood $(\mathrm{CV})$ with signs of moderate necrosis within the surrounding plates. Figure 11 shows hepatocytes with ovoid vesicular and prominent nucleoli indicated by (NV). It also shows coarse granular acidophilic cytoplasm, a well-organized portal areas and active blood circulation. Its central vein $(\mathrm{CV})$ contains blood with moderate number of polymorphs within the sinusoidal spaces as well as a near normal liver architecture.

Table 2. Effect of the Pre-treatment with Kigelia africana Ethanol Leaf Extracts on Some Non-enzyme Biochemical Markers.

\begin{tabular}{|c|c|c|c|c|}
\hline Treatment & C.B $(\mu \mathrm{mol} / \mathrm{L})$ & T.B $(\mu \mathrm{mol} / \mathrm{L})$ & $\mathrm{ALB}(\mathrm{g} / \mathrm{L})$ & T.P $(\mathrm{g} / \mathrm{L})$ \\
\hline Normal & $5.87 \pm 0.12$ & $13.60 \pm 0.10$ & $38.67 \pm 0.14$ & $58.33 \pm 0.25$ \\
\hline Silymarin & $6.75 \pm 0.34$ & $14.23 \pm 0.58$ & $42.00 \pm 0.14$ & $62.00 \pm 0.14$ \\
\hline $\mathrm{CCl}_{4}$ control & $58.45 \pm 0.48^{\mathrm{ab}}$ & $41.48 \pm 0.19^{\mathrm{ab}}$ & $97.67 \pm 0.75^{\mathrm{ab}}$ & $155.33 \pm 0.19^{\mathrm{ab}}$ \\
\hline 100 mg/kg/day KAELE & $38.75 \pm 0.75^{\mathrm{ab}}$ & $28.68 \pm 0.61^{\mathrm{ab}}$ & $65.50 \pm 0.77^{\mathrm{ab}}$ & $88.33 \pm 0.22^{\mathrm{ab}}$ \\
\hline 200 mg/kg/day KAELE & $10.80 \pm 0.56^{c}$ & $16.17 \pm 0.56^{c}$ & $43.50 \pm 0.42^{c}$ & $64.83 \pm 0.91^{c}$ \\
\hline 400 mg/kg/day KAELE & $8.73 \pm 0.17^{c}$ & $15.93 \pm 0.19^{c}$ & $41.00 \pm 0.21^{c}$ & $61.67 \pm 0.22^{\mathrm{c}}$ \\
\hline
\end{tabular}

Values are expressed as mean \pm SEM $(\mathrm{n}=5)$. Superscript $(\mathrm{a}, \mathrm{b}$ and $\mathrm{c})=$ significant changes $(P<0.05)$ compared to normal, slimarin and CCl 4 control, respectively. T.B $=$ Total bilirubin, C.B = Conjugated bilirubin, T.P = Total protein, ALB = Albumin, KAELE = Kigelia africana Ethanol Leaf Extract.

Table 3. Effect of Pre-treatment with Ethanol Leaf Extract of Kigelia africana on some Kidney function parameters.

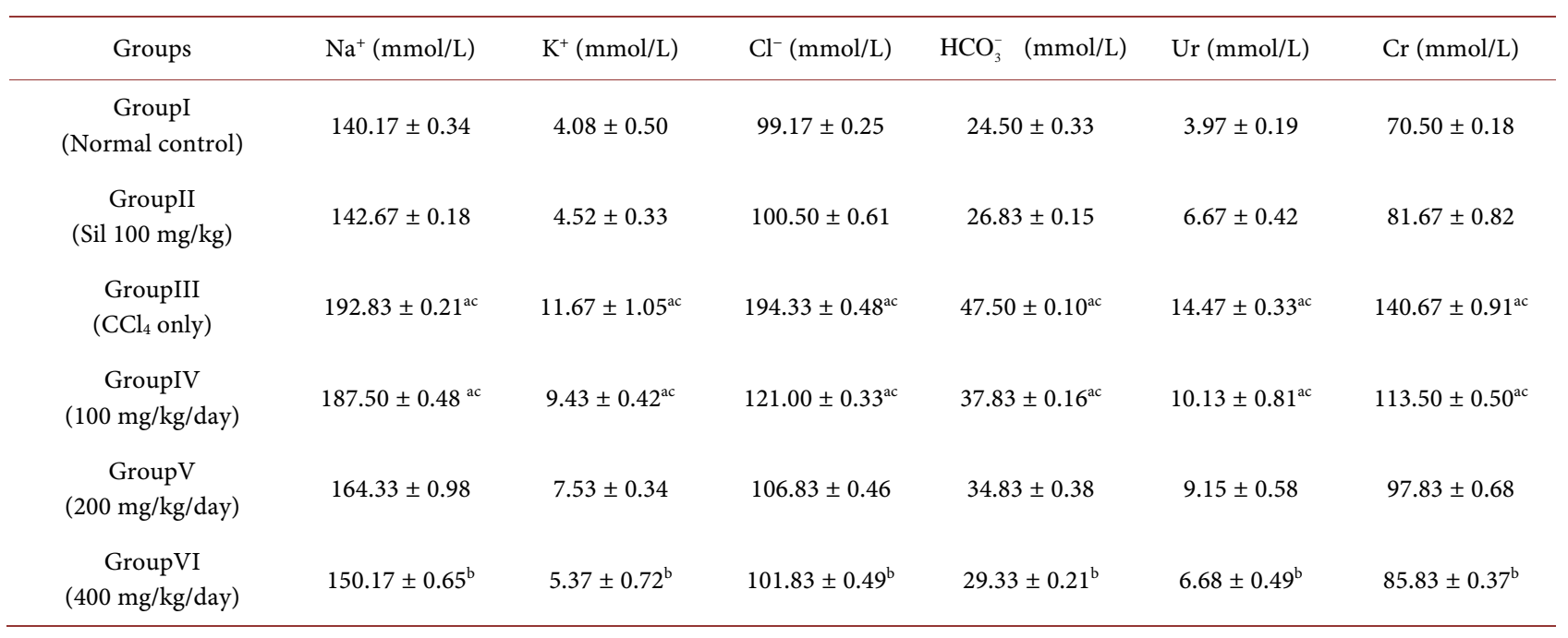

Values are expressed as mean \pm SEM $(\mathrm{n}=5)$. Superscript $(\mathrm{a}),(\mathrm{c})$ and $(\mathrm{b})=$ significantly different $(P<0.05)$ compared control and silymarin and CCl 4 respectively. 


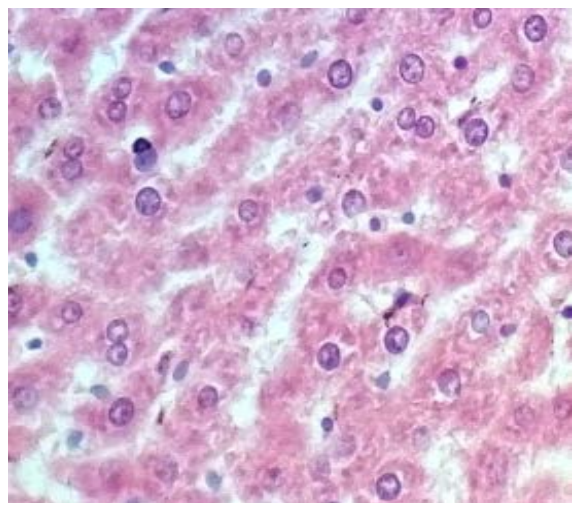

Figure 6. Control $(\mathrm{H} \& \mathrm{E} \times 400)$.

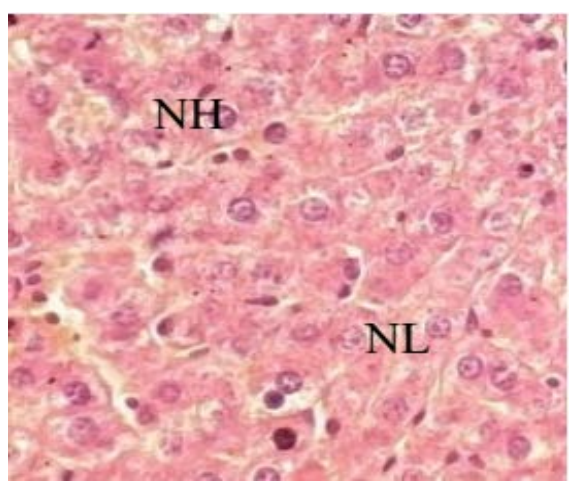

Figure 7. Silymarin $(100 \mathrm{mg} / \mathrm{kg})(\mathrm{H} \& \mathrm{E} \times 400)$.

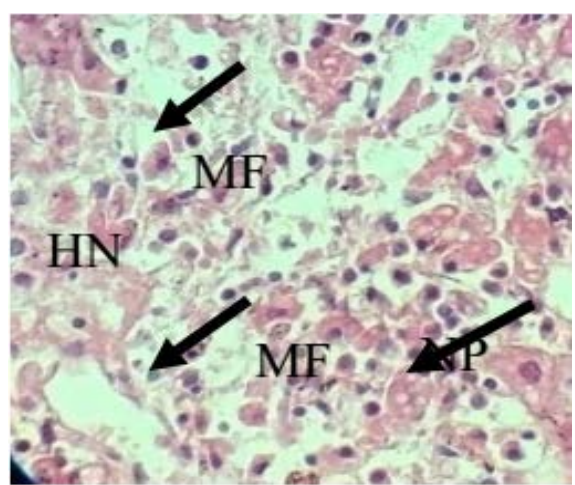

Figure 8. $\mathrm{CCl}_{4}(1 \mathrm{ml} / \mathrm{kg})(\mathrm{H} \& \mathrm{E} \times 400)$.

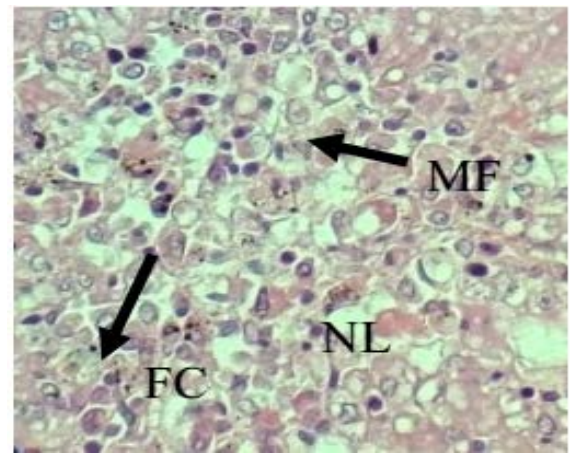

Figure 9. (100 mg/kg Ext) $(\mathrm{H} \& \mathrm{E} \times 400)$. 


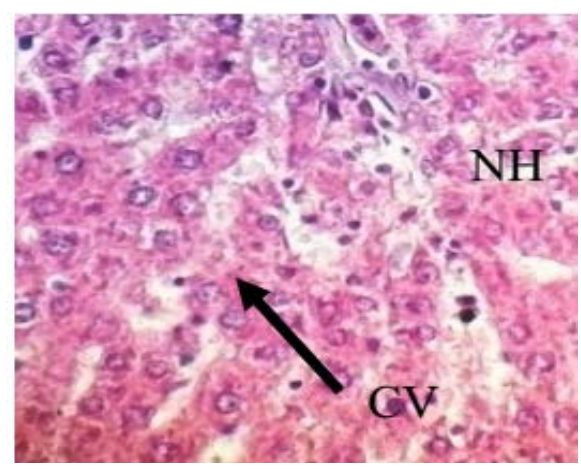

Figure 10. (200 mg/kg Ext) $(\mathrm{H} \& \mathrm{E} \times 400)$.

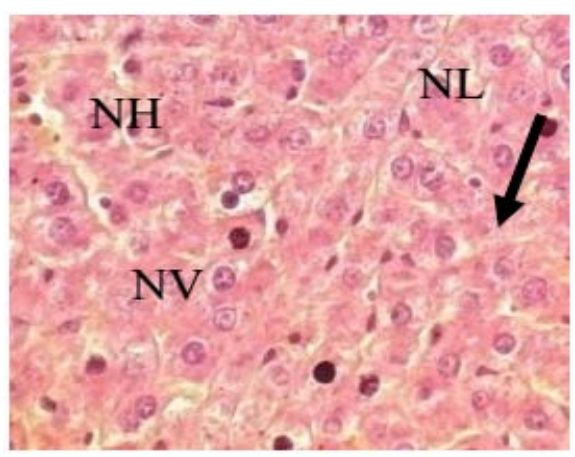

Figure 11. (400 mg/kg Ext) $(\mathrm{H} \& \mathrm{E} \times 400)$.

\section{Discussion}

The effect of $K$. africana ethanol leaf extract on carbon tetrachloride induced hepatorenal damage was investigated in this study. The elevated levels of the liver enzymes and other bio-indicators of hepatic toxicity from $\mathrm{CCl}_{4}$ treatment would be from the damage exerted by the said compound on hepatic tissue membranes and deleterious alterations in membrane permeability of the hepatocytes [31] [32].

The dose dependent activity of the extract of $K$. africana on the hepatic biomarkers could be attributed to a possible pre fortification of the hepatic defense mechanisms against the burden of $\mathrm{CCl}_{4}$ toxicity. $\mathrm{CCl}_{4}$ has been reported to be metabolized to trichloromethyl radical by CYP2E1 culminating in the formation of trichloromethyl peroxy radical, as well as autocatalytic lipid peroxidation provoked by the hepatic cellular membrane exposure to the formed radicals. It has also been shown to interfere with calcium balance causing the activation of enzymatic degradation and cytotoxicity. Additionally, it has been reported to cause sustained regenerative and proliferative changes in liver post toxicity which eventually causes an overwhelming repercussion on the DNA repair mechanism as increased cell division is directly proportional to increase in frequency of genetic damage [33].

The Phytochemical screening of the extract in this current study has revealed the presence of significant polyphenolic compounds which could have played some vital roles in the mechanism of the extract against hepatic and renal toxic- 
ity.

Therefore, the activity of the $K$. africana on hepatorenal toxicity could have been from attenuating action of compounds like flavonoids on the ROS generated from $\mathrm{CCl}_{4}$ toxicity hence mitigating lipid peroxidation as well as cellular membrane destruction in this study. Flavonoids have negligible antioxidant activity which could either be directly or indirectly from uric acid formed during the depolymerization of flavonoid [34]. The pro inflammatory responses to $\mathrm{CCl}_{4}$ treatment could also have been inhibited by the flavonoid content of $K$. africana in this study. This is possible via its inhibitory activity on pro inflammatory enzymes such as cyclooxygenases and lipoxygenases capable of generating ROS and RNS. Flavonoids have been shown to exhibit their actions through effects on common membrane permeability, and by inhibition of membrane-bound enzymes such as the AT-Pase and phospholipase [35] and this property may possibly explain the mechanisms of antioxidative action of $K$. pinnata leaf extract.

The result of $K$. africana in this current study could also have been buttressed by the terpenoids content of the extract. This compound is lipophilic [36] which make hepatocytes membrane highly permeable to it, allowing for more effective action and inhibition of cellular mechanisms exacerbating ROS production. Terpenoids have also been associated with decreased cellular proliferation through activation of necrotic and apoptotic pathways. This action could have helped in mitigating the burden of hyperplasia from $\mathrm{CCl}_{4}$ treatment in this current study, thus alleviating the damage on DNA repair mechanisms of the hepatocytes and renal cells [37]. Terpenoids have also been reported to mitigate inflammation through myriads of actions like inhibition of pro inflammatory enzymes among others [38]. Saponins and phenols also present could have contributed to the overall resistance offered against the toxic effect of $\mathrm{CCl}_{4}$, however, the mechanism of action remains elusive.

This is in tandem with the popular opinion that serum levels of transaminase return to normal with the healing of hepatic parenchyma and the regeneration of hepatocytes. Effective control of ALP levels points towards an improvement in the secretory mechanism of hepatic cells. It would not be out of place to state that ALT is more specific for liver damage than AST as mentioned earlier, the increase in ALT activity is usually due to hepatocellular injury and accompanied by an increase in AST. An increase in ALP reflects the pathological alteration in biliary flow [39] [40].

The results of bilirubin and total protein in this study suggest an improvement in the hepatic cell's secretory mechanism, as also evident by the result of the extract on liver architecture. Additionally, the considerable rise in level of plasma albumin and total proteins in this study could have been from increases in the plasma protein thiols activities, as good hepatoprotective effects. The result of this study posits a possible membrane stabilizing activity of the $K$. africana on hepatocytes.

Also, many metabolism disorders including serum electrolytes, urea and creatinine derangement are possible in the presence of carbon tetrachloride over 
dosage [4]. Increased concentration of serum urea and creatinine are considered for investing drug induced nephrotoxicity in animals and man [5]. Serum creatinine is an important indicator of real health disease because it is easily measured by-product of muscle metabolism. Creatinine is primarily synthesized in the liver and kidney and after phosphorylation turns to a high energy compound "phosphocreatine". Creatinine, a by-product of catabolism of phosphocreatine is chiefly filtered out of the blood by the kidneys. Therefore, if the filtration is deficient there is a rise in creatinine level in the blood. The decline in kidney filtration ability evidenced by the results of creatinine and electrolytes observed from $\mathrm{CCl}_{4}$ treatment was reversed by the extract in a dose depended fashion. The result of blood urea nitrogen (BUN) is synonymous to creatinine in this study in that it is made in the liver and filtered out by the kidney. Urea, a waste product of protein catabolism can rise when the kidney is defective. However, heart failure, dehydration, poor circulation or a diet high in protein can also make BUN level higher. A lower BUN level signals chronic liver disease though it is not used as a signal but confirmatory. The elevation of urea and creatinine levels in the serum is taken as the index of nephrotoxicity.

The abnormality of the liver architecture with injuries and fatty changes is consistent with the result of liver enzymes which infers disintegration of hepatocytes from $\mathrm{CCl}_{4}$ as well as cellular regeneration from KEALE administration. Nadro and Onoagbe [41] reported folkoric uses of the plant leaves in the management and control of jaundice in some parts of the North East of Nigeria.

\section{Conclusion}

In conclusion needless to say that the efficacy of any hepatoprotective drug is dependent on its capacity of either reducing the harmful effects or restoration of normal hepatic physiology. Kigelia africana ethanolic leaf extract mitigates the toxic effect of $\mathrm{CCl}_{4}$ on hepatorenal functions in this study.

\section{Funding Information}

This research was privately funded by the authors.

\section{Conflicts of Interest}

The authors declare no conflicts of interest regarding the publication of this paper.

\section{References}

[1] Rajkapoor, B., Venugopal, Y., Anbu, J., Harikrishnan, N., Gobinath, M. and Ravichandran, V. (2008) Protective Effect of Phyllanthuspolyphyllus on Acetaminophen Induced Hepatotoxicity in Rats. Pakistan Journal of Pharmaceutical Sciences, 21, 57-62.

[2] Patel, R.K., Patel, M.M., Patel, M.P., Kanzaria, N.R., Vaghela, K.R. and Patel, N.J. (2008) Hepatoprotective Activity of Moringa oleifera Lam Fruit on Isolated Rat Hepatocytes. Pharmacology Research, 4, 118-123. 
[3] Blumenthal, D., Brunton, L., Parker, K., Lazo, J.S. and Buxton, I. (2006) Goodman and Gilman's Pharmacological Basis of Therapeutics Digital Edition. McGraw-Hill Professional, New York, 111-117.

[4] Kale, R.H., Halde, U.K. and Biyani, K.R. (2012) Protective Effect of Aqueous Extract of Uraria picta on Acetaminophen Induced Nephrotoxicity in Rats. International Journal of Research on Pharmacy and Biomedical Sciences, 3, 110-113.

[5] Bennit, W.R., Parker, R.A., Elliot, W.C., Gilbert, D. and Houghton, D. (1982) Sex Related Differences in the Susceptibility of Rats to Gentamicin Nephrotoxicity. Journal of Infectious Diseases, 145, 370-374. https://doi.org/10.1093/infdis/145.3.370

[6] Chahinez, H., Abdalla, E. and Saad, M.H. (2012) A Comparative Study on the Antidiabetic Activity of Extracts of Some Algerian and Sudanese Plants. Journal of Diabetes and Endocrinology, 3, 25-28. https://doi.org/10.5897/JDE12.002

[7] Banskota, A.H., Tezuka, Y., Adnyana, I.K., Xiong, Q., Hase, K. and Tran, K.Q. (2000) Hepatoprotective Effect of Commbretum quadrangulare and Its Constituents. Biological and Pharmaceutical Bulletin, 23, 456-460.

https://doi.org/10.1248/bpb.23.456

[8] Christian, A., David, D.O., Yaw, D.B. and Newman, O. (2013) Anti-Inflammatory and Analgesic Activities of African Medicinal Plants. Medicinal Plant Research, 12, 725-752. https://doi.org/10.1016/B978-0-12-405927-6.00019-9

[9] Charlotte, R. and Dorthe, J. (2005) Kigelia africana (Lam.) Benth. Phytotrade Africa, No. 108 .

[10] Bharti, N., Singh, S., Fermida, N. and Amir, A. (2006) Isolation and in Vitro Antiamoebic Activity of Iridoids Isolated from Kigelia pinnata. Arkivoc, 10, 69-76. https://doi.org/10.3998/ark.5550190.0007.a09

[11] Owolabi, O.J., Amaechina, F.C. and Eledan, A.B. (2008) Central Nervous System Stimulant Effect of the Ethanolic Extract of Kigelia africana. Journal of Medicinal Plants Research, 2, 20-23.

[12] Olaleye, M.T. and Rocha, B.T. (2008) Acetaminophen-Induced Liver Damage in Mice: Effects of Some Medicinal Plants on the Oxidative Defense System. Experimental Toxicology and Pathology, 17, 319-327.

https://doi.org/10.1016/j.etp.2007.10.003

[13] Nayarko, A.K., Okine, L.W.N., Wedzi, R.K., Addo, P.A. and Ofsuhene, M. (2005) Subchronic Toxicity Studies of the Antidiabetic Herbal Preparation ADD-199 in the Rat: Absence of Organ Toxicity and Modulation of Cytochrome. Journal of Ethnopharmacology, 97, 319-325. https://doi.org/10.1016/j.jep.2004.11.021

[14] Patrizia, P.A., Giuseppina, M., Stefania, M., Marisa, S. and Rokia, P.A. (2008) Anti-Inflammatory Activity of Verminoside from Kigelia africana and Evaluation of Cutaneous Irritation in Cell Cultures and Reconstituted Human Epidermis. Journal of Natural Products, 68, 1610-1614. https://doi.org/10.1021/np058046z

[15] Houghton, P.J. (2002) The Sausage Tree (Kigelia pinnata): Ethnobotany and Recent Scientific Work. South Africa Journal of Botany, 68, 14-20.

https://doi.org/10.1016/S0254-6299(15)30434-8

[16] Jameela, L., Hilary, C.H., Aroa, R.I., Christoph, D., Monika, S. and Brian, D.Z. (2011) The Ovariectomized Mice and Rats in Osteoporosis Research: Animal Model. Sprinter Verlag, vol. 3, 43-47.

[17] National Research Council (1996) Guide for the Care and Use of Laboratory Animals. National Academic Press, Washington DC. 
[18] Harborne, J.B. (1973) Phytochemical Methods. Chapman and Hall, Limited, London, 49-188.

[19] Senthilkumar, P.K. and Reetha, D. (2009) Screening of Antimicrobial Properties of Certain Indian Medicinal Plants. Journal of Phytology, 1, 193-198.

[20] Nweze, E.L., Okafor, J.L. and Njoku, O. (2004) Antimicrobial Activityies of Methanolic Extracts of Trume guineesis (Scchumn and Thorn) and Morinda lucinda Used in Nigerian Herbal Medicinal Practice. Journal of Biological Research and Biotechnology, 2, 34-46. https://doi.org/10.4314/br.v2i1.28540

[21] Ferguson, A. (1956) Phytochemical Screening of the Leaf Extracts of Hyptis spicigera Plant. African Journal of Pure and Applied Chemistry, 8, 83-88. https://doi.org/10.5897/AJPAC2014.0560

[22] Amy, R. and Deyao, G. (1994) Synthensis of Nonequilibrium Reactive Distillation Process by MINLP Optimization. ALChe Journal, 40, 1479-1487. https://doi.org/10.1002/aic.690400907

[23] Obdoni, B.O. and Ochuko, P.O. (2001) Phytochemical Studies and Comparative Efficacy of the Crude Extracts of Some Homostatic Plants in Edo and Delta States of Nigeria. Global Journal of Pure and Applied Science, 8, 203-208. https://doi.org/10.4314/gjpas.v8i2.16033

[24] Edeoga, H.O., Okwu, D.E. and Mbaebie, B.O. (2005) Phytochemical Constituents of Some Nigerian Medicinal Plants. African Journal of Biotectnology, 4, 685-688. https://doi.org/10.5897/AJB2005.000-3127

[25] Reitman, S. and Frankel, S. (1957) A Colorimetric Method for the Determination of Serum Glutamic Oxalacetic and Glutamic Pyruvic Transaminases. American Journal of Clinical Pathology, 28, 56-63. https://doi.org/10.1093/ajcp/28.1.56

[26] Bowers, G.N.J. and Mc-Comb, R.B. (1966) A Continuous Spectrophotometric Method for Measurement the Activity of Serum Alkaline Phosphatase. Clinical Chemistry, 12, 73-78. https://doi.org/10.1093/clinchem/12.2.70

[27] Doumas, B.T., Kwok-Cheung, P.P., Perry, B.W., Jendrzejczak, B., McComb, R.B., Schaffer, R., et al. (1985) Candidate Reference Method for Determination of Total Bilirubin in Serum: Development and Validation. Clinical Chemistry, 31, 1779-1789. https://doi.org/10.1093/clinchem/31.11.1779

[28] Reinhold, J.G. (1953) Total Protein, Albumin and Globulin. Standard Methods of Clinical Chemistry, 1, 88. https://doi.org/10.1016/B978-0-12-609101-4.50019-8

[29] Lipitskaia, I., Kotkina, T.I., Tarasov, A.V. and Titov, V.N. (1989) Kineticheskiŭ metod opredeleniia kreatinina po reaktsii Iaffe. A Kinetic Method of Determining Creatinine Using the Jaffé Reaction. Lab Delo, 2, 37-42.

[30] Carlton, H. (1979) Histological Techniques. 4th Edition, Oxford University Press, New York.

[31] Fakarazi, S., Hairuszah, I. and Nanthini, U. (2008) Moringa oleifera Lam Prevents Acetaminophen Induced Liver Injury through Restoration of Glutathione Level. Food Chemistry and Toxicology, 46, 2611-2615. https://doi.org/10.1016/j.fct.2008.04.018

[32] Ansari, J.A. and Asif, R. (2012) Hepatoprotective Effect of Tabernaemontana divaricate against Acetaminophen Induced Liver Toxicity. Medical Chemistry and Drug Discovery, 3, 146-151.

[33] Weber, L.W., Boll, M. and Stampel, A. (2003) Hepatotoxicity and Mechanism of Action of Haloalkanes: Carbon Tetrachloride as a Toxicological Model. Critical Reviews in Toxicology, 33, 105-136. https://doi.org/10.1080/713611034 
[34] Williams, R.J., Spencer, J.P. and Rice-Evans, C. (2004) Flavonoids: Antioxidants or Signaling Molecules? Free Radical Biology \& Medicine, 36, 838-849. https://doi.org/10.1016/j.freeradbiomed.2004.01.001

[35] Li, H., Wang, Z. and Liu, Y. (2003) Review in the Studies on Tannins Activity of Cancer Prevention and Anticancer. Journal of Chinese Medicinal Materials, 26, 444-448.

[36] Raut, J.S. and Karuppayil, S.M. (2014) A Status Review on the Medicinal Properties of Essential Oils. Industrial Crops and Products, 62, 250-264. https://doi.org/10.1016/j.indcrop.2014.05.055

[37] Lesgards, J.F., Baldovini, N., Vidal, N. and Pietri, S. (2014) Anticancer Activities of Essential Oils Constituents and Synergy with Conventional Therapies: A Review. Phytother Research, 28, 1423-1446. https://doi.org/10.1002/ptr.5165

[38] Georgiev, M.I., Ivanovska, N., Alipieva, K., Dimitrova, P. and Verpoorte, R. (2013) Harpagoside: From Kalahari Desert to Pharmacy Shelf. Phytochemistry, 92, 81. https://doi.org/10.1016/j.phytochem.2013.04.009

[39] Hewitt, L.A., Ayotte, P. and Plaa, G.L. (1986) Modifications in Rat Hepatobiliary Function Following Treatment with Acetone, 2-Butanone, 2-Hexanone, Mirex, or Chlordecone and Subsequently Exposed to Chloroform. Toxicology and Applied Pharmacology, 83, 465-473. https://doi.org/10.1016/0041-008X(86)90229-2

[40] Wandiahyel, Y.G., Hickson, S., Thagriki, D.S. and Emmanuel, N.S. (2018) Medicinal Potentials of Kigelia africana Leaf Fractions on Rats Induced $\mathrm{CCl}_{4}$ Toxicity. Chemistry Research Journal, 3, 123-129.

[41] Nadro, M.S. and Onoagbe, I.O. (2014) Protective Effects of Aqueous and Ethanolic Extracts of the Leaf of Cassia italica in $\mathrm{CCL}_{4}$-Induced Liver Damage in Rats. American Journal of Research Communication, 2, 122-130.

\section{Abbreviations}

KAELE; Kigelia africana ethanolic leaf extract,

ROS; reactive oxygen species. 